\title{
OUTCOME OF COMBINED SURGICAL TREATMENT IN CASE OF CHRONIC VENOUS LEG ULCER- A PROSPECTIVE STUDY
}

Manjunath Honnavalli Rudrappaㄹ, Vasudev Murthy Kumar ${ }^{2}$

${ }^{1}$ Assistant Professor, Department of General Surgery, Sapthagiri Institute of Medical Sciences and Research Centre, Bangalore, Karnataka.

${ }^{2}$ Associate Professor, Department of General Surgery, Akash Institute of Medical Sciences and Research Centre, Bangalore, Karnataka. ABSTRACT

\section{BACKGROUND}

Venous leg ulcers are the most serious type of chronic venous incompetence. Chronic leg ulcers (CLU) affect $0.6 \%$ - 3\% of those aged over 60 years, increasing to over $5 \%$ of those aged over 80 years. CLU is a common cause of morbidity and its prevalence in the community ranges from $1.9 \%$ to $13.1 \%$. Treatment and recurrence prevention methods remain under discussion and research. Aims and Objectives- To evaluate the effect of combined surgical treatment in outcome of venous leg ulcers.

\section{MATERIALS AND METHODS}

The study was descriptive. Patients hospitalised with venous leg ulcer in the Department of General Surgery were included in the study. The study group comprised of 50 patients subjected to treatment for leg ulcerations including 35 men and 15 women, aged above 30 yrs. The treatment method included superficial surgery which involved SFJ and SPJ disconnection with stripping and avulsion and split thickness skin grafting (STSG) over the prepared venous ulcer.

\section{RESULTS}

Amongst patients evaluated at discharge, the healing of the transplant was as follows- In case of 35 patients $90 \%-100 \%$, in 6 patients $75 \%-89 \%$, in 4 patients $50 \%-74 \%$ and in 5 patients less than $50 \%$.

\section{CONCLUSION}

Combined surgery is an effective method in treatment of venous leg ulcers. Earlier qualification for this type of surgery will improve patient outcome.

\section{KEYWORDS}

Leg Ulcers, Skin Graft.

HOW TO CITE THIS ARTICLE: Rudrappa MH, Kumar VM. Outcome of combined surgical treatment in case of chronic venous leg ulcer- a prospective study. J. Evolution Med. Dent. Sci. 2018;7(15):1822-1824, DOI: 10.14260/jemds/2018/411

\section{BACKGROUND}

In the course of a lifetime, almost $10 \%$ of the population will develop a chronic wound with a wound-related mortality rate of $2.5 \% .[1]$ While there are few Indian studies on the epidemiology of chronic wounds, one study estimated the prevalence at 4.5 per 1000 population.[2] Venous leg ulcers are the most serious type of chronic venous incompetence.[3] Chronic leg ulcers (CLU) affect $0.6 \%$ - 3\% of those aged over 60 years, increasing to over $5 \%$ of those aged over 80 years. CLU is a common cause of morbidity and its prevalence in the community ranges from $1.9 \%$ to $13.1 \% .{ }^{[4]}$ It is thought that the incidence of ulceration is rising as a result of aging population and increased risk factors for atherosclerotic occlusion such as smoking, obesity and diabetes.

The aetiology of leg ulcers is usually associated with disorders of chronic venous insufficiency. Theories considering the development of venous ulcerations are based on macro- and micro-circulation changes.

'Financial or Other Competing Interest': None.

Submission 18-03-2018, Peer Review 31-03-2018,

Acceptance 02-04-2018, Published 09-04-2018.

Corresponding Author:

Dr. Vasudev Murthy Kumar,

\#525, Tank Road,

Doddballapur-561203,

Bangalore Rural District,

Karnataka.

E-mail: murthy_dbp@yahoo.com

DOI: $10.14260 /$ jemds $/ 2018 / 411$
Changes in microcirculation lead to an increase of venous pressure, which results in impaired blood outflow. This may be caused by weakening of muscular function, deep venous thrombosis, reduced venous capacity, occlusion of collecting veins and valvular insufficiency.[5]

Venous ulcers are often recurrent and open ulcers can persist from weeks to many years. Severe complications include cellulitis, osteomyelitis and malignant changes.[6]

\section{Aims and Objectives}

To determine combined surgical treatment results considering Venous Ulcers, using a combined procedure:

1. The surgical interruption of reflux in the superficial and perforating veins to reduce venous hypertension in the entire leg and/or the affected area.

2. The surgical procedure involving the ulcer- skin grafts of intermediate thickness.

\section{MATERIALS AND METHODS}

The study was a descriptive type of study conducted over a period of 18 months.

\section{Inclusion Criteria}

- All patients with primary venous leg ulcer.

- $\quad$ Age- above 30 years.

\section{Exclusion Criteria}

- Secondary and recurrent venous ulcer.

- Ulcer with arterial and malignant aetiology. 
- Ulcers outside the gaiter region.

- Pregnant ladies.

The study was done on 50 patients subjected to first-time treatment of lower leg venous ulcerations. The study group comprised of 35 male and 15 female patients, aged above 30 years. All patients were subjected to a thorough medical interview and physical examination.

\section{Surgical Procedure}

Patients with superficial venous incompetence in the absence of deep venous incompetence on duplex imaging were offered corrective superficial venous surgery to the affected limb. Superficial surgery involved saphenofemoral or saphenopopliteal disconnections with stripping and avulsion. Incompetent perforating veins detected in the absence of deep venous insufficiency were localised pre-operatively with duplex and ligated or avulsed through small incisions.

Tangential excision of their leg ulcers followed by autografting with meshed split-thickness skin graft (STSG). This entailed mechanical debridement of necrotic tissues, lipodermatosclerotic skin and subcutaneous calcifications immediately followed by mesh skin grafting. Mesh grafting consists of harvesting an STSG $(0,3 \mathrm{~mm}$ thick) with a dermatome and expanding this graft with a mesher. Insufficient perforator veins are ligated superficially to the fascia. Donor grafts are obtained from the thigh. In addition, immobilising devices are used if skin grafts are applied onto mobile surfaces. The vast majority of the patients are discharged after an average period of 7 - 10 days. Compression therapy is continued after discharge. Early standard post graft follow-up consists of 3 controls, in the 3rd, 6 th and 12 th week in the outpatient clinic.

Clinical changes and treatment results of the ulcerations (graft healing) were analysed as percentage of graft uptake and healing as below:

\begin{tabular}{|c|c|}
\hline Graft Incorporation Rate & Outcome \\
\hline $90-100 \%$ & Very Good \\
\hline $75-89 \%$ & Good \\
\hline $50-74 \%$ & Satisfactory \\
\hline$<50 \%$ & Unsatisfactory \\
\hline
\end{tabular}

\section{RESULTS}

Fifty patients were subjected to combined surgical treatment consisting of surgery for reflux disease and autogenous skin grafts of intermediate thickness.

Table 1 shows the surface of the ulceration prior to treatment, most of the patients were under $10-20 \mathrm{~cm}^{2}$ surface area.

\begin{tabular}{|c|c|c|}
\hline Surface of Ulceration & No. of Pts. & Percentage (\%) \\
\hline$<10 \mathrm{~cm}^{2}$ & 10 & $20 \%$ \\
\hline $10-20 \mathrm{~cm}^{2}$ & 38 & $76 \%$ \\
\hline$>20 \mathrm{~cm}^{2}$ & 2 & $4 \%$ \\
\hline $\begin{array}{c}\text { Table 1. Number of Patients depending on the Surface } \\
\text { of the Ulceration on Admission to the Hospital }\end{array}$ \\
\hline
\end{tabular}

Table 2 shows graft incorporation evaluated on discharge from the hospital: $90 \%-100 \%$ in 35 patients, $75 \%-89 \%$ in 6 patients, $50 \%-74 \%$ in 4 patients and $<50 \%$ in 5 patients.

\begin{tabular}{|c|c|c|}
\hline Healed Surface & No. of Pts. & Percentage (\%) \\
\hline $90-100 \%$ & 35 & $70 \%$ \\
\hline $75-89 \%$ & 6 & $12 \%$ \\
\hline $50-74 \%$ & 4 & $8 \%$ \\
\hline$<50 \%$ & 5 & $10 \%$ \\
\hline Table 2. Patient Characteristics depending on the \\
Healed Surface at Discharge from the Hospital \\
\hline
\end{tabular}

Best results were obtained amongst patients with the area of ulceration of $<10 \mathrm{~cm}^{2}, 90 \%-100 \%$ graft incorporation was observed in $90 \%$ of cases. In patients with an ulceration surface, $10-20 \mathrm{~cm}^{2}, 90 \%-100 \%$ graft incorporation was observed in $74.28 \%$ of cases.

Figure 1 shows dependency between healed surface and size of ulceration before surgery. Best results were obtained amongst patients with the area of ulceration of $<10 \mathrm{~cm}^{2}$, $90 \%-100 \%$ graft incorporation was observed in $90 \%$ of cases. In patients with an ulceration surface of $10-20 \mathrm{~cm}^{2}$, $90 \%-100 \%$ graft incorporation was observed in $74.28 \%$ of cases.

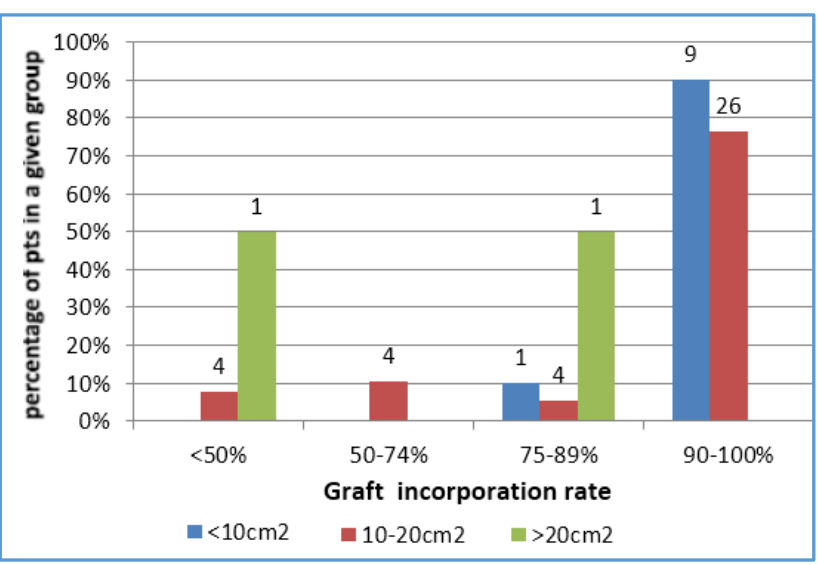

Figure 1. Dependency between Healed Surface and Size of Ulceration before Surgery

\section{DISCUSSION}

Venous ulcerations constitute chronic wounds, where the healing process is long lasting and complex. The selection of the appropriate therapeutic method remains a problem faced by various medical specialists. The effectiveness of treatment is influenced by many factors, related to both aetiology and initial local condition of the ulceration as well as the patient's general condition.

Graft incorporation following our treatment methods was evaluated upon hospital discharge. Results were as follows: More than $90 \%$ graft incorporation in $70 \%$ of patients and healing of more than $50 \%$ of the surface of the ulceration in $92 \%$ of patients. Failure during the early postoperative period was mainly associated with the duration and extent of the ulceration. Similar results, more than $90 \%$ of graft healing were observed by other Authors based on several years of follow-up.[7,8]

In case of treatment and compression therapy, it is estimated that the use of the above-mentioned methods will lead to $12 \%$ to $74 \%$, and according to other Authors $40 \%$ to $80 \%$ of ulceration healing during a period of 12 weeks. ${ }^{[9,10,11]}$

Studies comparing both methods show a greater percentage of healed ulceration surface in case of patients subjected to skin grafting as compared to those subject to 
compression therapy only. These studies demonstrated the significant difference in the local healing rate, which is in favour of the first group. ${ }^{[12]}$

A significant problem affecting the effectiveness of venous ulceration treatment is their recurrence, which was observed by most authors, regardless the therapeutic method used. However, literature data showed a much less frequent recurrence rate after surgical intervention, which is evidence of its greater efficacy.[13,14,15]

Without doubt conservative treatment continues to be the mainstay of treatment for venous leg ulcers, especially in case of small ulcerations and is an important element prior to surgical intervention. However, it has many disadvantages and contraindications.[16,17]

There are also patients where compression therapy and local treatment does not lead to healing, and the process is long-lasting. These are mainly elderly patients with long lasting and extensive ulcerations. In such cases, skin grafts seem more effective.[18,19]

Surgical treatment is often regarded as the method of last resort when there are no positive effects following conservative treatment. However, the above-mentioned results and available study data indicate the legitimacy of early surgical intervention, as the method reducing the duration of treatment and risk of recurrence which will translate into lower costs and improve the patient's quality of life.

\section{CONCLUSION}

Surgical treatment with the use of skin grafts is an effective and rapid therapeutic method, considering chronic venous leg ulcers. In order to obtain good graft healing using a combined surgical procedure is found to be effective. Early qualification for surgery allows obtaining good treatment results in short time.

\section{REFERENCES}

[1] Chatterjee SS. Venous ulcers of the lower limb: where do we stand? Indian J Plast Surg 2012;45(2):266-74.

[2] Shukla VK, Ansari MA, Gupta SK. Wound healing research: a perspective from India. Int J Low Extrem Wounds 2005;4(1):7-8.

[3] Porter JM, Moneta GL. Reporting standards in venous disease: an update. International Consensus Committee on Chronic Venous Disease. J Vasc Surg 1995;21(4):635-45.

[4] Rayner R, Carville K, Keaton J, et al. Leg ulcers: atypical presentations and associated comorbidities. Wound Practice and Research 2009;17(4):168-85.

[5] Araki CT, Back TL, Padberg FT, et al. The significance of calf muscle pump function in venous ulceration. J Vasc Surg 1994;20(6):872-7.

[6] Meissner MH, Moneta G, Burnand $\mathrm{K}$, et al. The hemodynamics and diagnosis of venous disease. J Vasc Surg 2007;46 Suppl S:S4-S24.

[7] Staniszewski R, Stanisić M, Winckiewicz M, et al. Przydatność przeszczepów skóry w leczeniurozległych owrzodzeń żylnych. Post Dermatol i Alergoz 2005;22(2):70-6.
[8] Flisiuk M. Analiza odległych wyników leczenia rozległych owrzodzeń goleni. Praca doktorska, Lublin 2011.

[9] Wiszniewski A, Meissner AJ, Jaśkowiak W, et al. Kompresoterapia z użyciem dwóch opasek elastycznych $\mathrm{w}$ leczeniu żylnych owrzodzeń golenimetoda bandażowania. IV Kongres Polskiego Towarzystwa Flebologicznego 20-22.06.2003, Wrocław. Przegl Flebolog 2003;11(2):98.

[10] Callam MJ, Dale JJ, Ruckley CV, et al. Lothian and forth valley leg ulcer healing trial-part 2: knitted viscose dressing versus a hydrocolloid dressing in the treatment of chronic leg ulceration. Phleology 1992;7(4):142-5.

[11] Duby T, Hoffman D, Cameron J, et al. A randomized trial in the treatment of venous leg ulcers comparing short stretch bandages, four-layer bandage system, and a long stretch paste bandage system. Wounds: A Compendium of Clinical Research and Practice 1993;5:276-9.

[12] Omar AA, Mavor AI, Jones AM, et al. Treatment of venous leg ulcers with dermagraft. Eur J Vasc Endovasc Surg 2004;27(6):666-72.

[13] Barwell JR, Davies CE, Deacon J, et al. Comparison of surgery and compression with compression alone in chronic venous ulceration (ESCHAR study): randomised controlled trial. Lancet 2004;363(9424):1854-9.

[14] Zamboni P, Cisno C, Marchetti F, et al. Minimally invasive surgical management of primary venous ulcers vs. compression treatment: a randomized clinical trial. Eur J Vasc Endovasc Surg 2003;25(4):313-8.

[15] McDaniel HB, Marston WA, Farber MA, et al. Recurrence of chronic venous ulcers on the basis of clinical, etiologic, anatomic, and pathophysiologic criteria and air plethysmography. J Vasc Surg 2002;35(4):723-8.

[16] Barwell JR, Taylor M, Deacon J, et al. Surgical correction of isolated superficial venous reflux reduces long term recurrence rate in chronic venous leg ulcers. Eur J Vasc Endovasc Surg 2000;20(4):3638.

[17] Stacey MC, Burnand KG, Layer GT, et al. Calf pump function in patients with healed venous ulcers is not improved by surgery to the communicating veins or by elastic stocking. Br J Surg 1988;75(5):436-9.

[18] Kjaer ML, Jorgensen B, Karlsmark T, et al. Does the pattern of venous insufficiency healing of venous leg ulcer after skin transplantation? Eur J Vasc Endovasc Surg 2003;25(6):562-7.

[19] Jankūnas V, Samsanovičius D, Pundzius J, et al. The influence of the applied method of treatment upon the Speer of healing of venous leg ulcer and patient's quality of life. Przegl Flebolog 2004;12(3):101-7. 